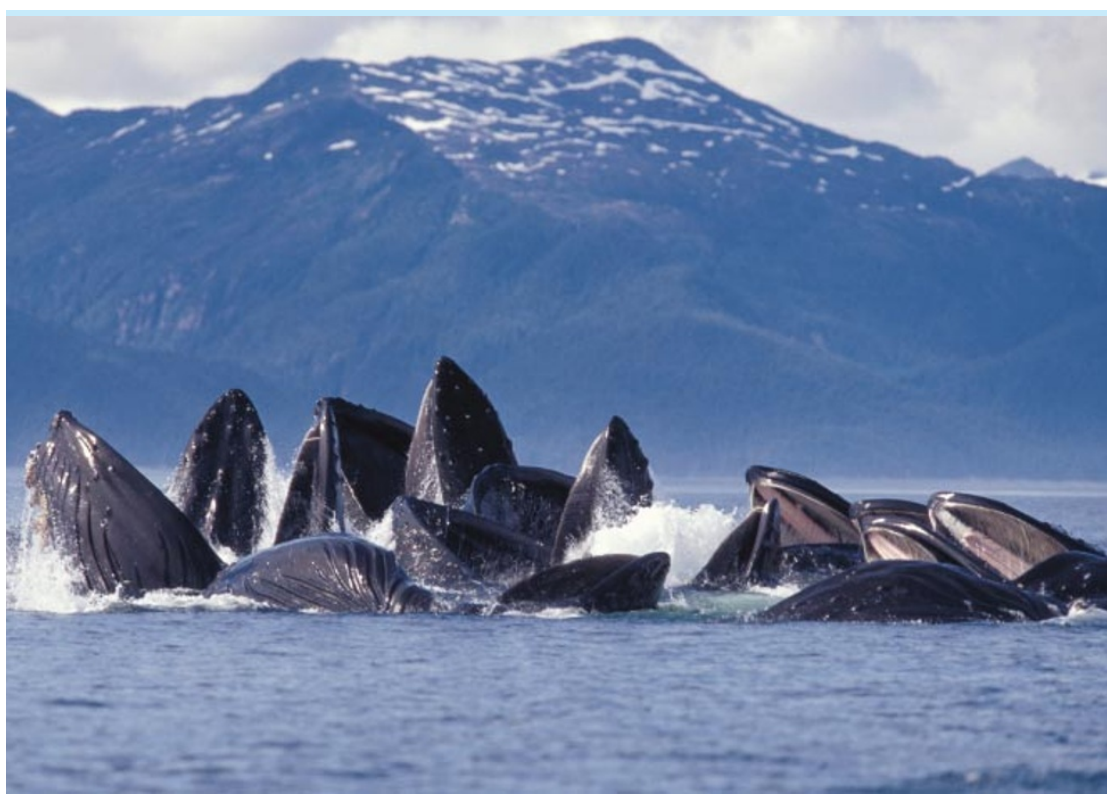

Making a splash: an estimate of historic humpback-whale populations has divided biologists.

\title{
Whale genetics study leaves conservationists all at sea
}

\section{Tom Clarke and Jonathan Knight}

Conservationists fear that a study on whale populations, which seems to back the need for more restrictions on whaling, could ultimately undermine their cause.

The analysis, published on 25 July, suggests that the population of humpback and fin whales before widespread whaling began in the nineteenth century was about 12 times larger than previously thought (J. Roman and S. R. Palumbi Science 301, 508-510; 2003). This could have important implications, as the International Whaling Commission (IWC) says that commercial whaling can resume when populations approach their pre-whaling size. But critics say the analysis is flawed and should not be used to set policy.

Estimates of past population levels are usually based on whaler's logbooks and population growth rates. Palumbilooked instead at the genetic variation in current whale populations by comparing the sequence of a small region of DNA collected from several hundred animals. The greater the degree of variation, the larger the historic population.

The analysis suggests that the North Atlantic once supported 240,000 humpbacks, far more than the IWC's pre-whaling estimate of 20,000 . There are about 10,000 humpbacks in the North Atlantic today.

"The numbers strongly caution against the return to whaling for humpback and fin whales," says Stephen Palumbi, a population biologist at Stanford University in California, and one of the study's authors.

Yet some whale experts say that Palumbi's conclusion is a gross overestimate. "It's completely out of the realm of reality," says Phillip Clapham, a whale biologist at the Northeast Fisheries Science Center in Woods Hole, Massachusetts, who opposes the resumption of commercial whaling. "To suggest that these figures be used as a target for the managed recovery of whale populations is inappropriate," he says.

One problem is that the estimate of how frequently genetic mutations occur has a big influence on the analysis, says geneticist Per Palsbøll of the University of California, Berkeley. A higher but also plausible mutation rate would have shown that the pre-whaling humpback population was only 2,400. Interbreeding between southern and northern populations could also have increased the genetic diversity, making historic populations seem larger than they were, he says.

Palumbi says that the mutation rate he used is consistent with the evolutionary history of whales and related species, adding that interbreeding would not significantly alter his results. He notes that other techniques have not been peer-reviewed or subject to the scrutiny that his paper is undergoing.

If pro-whaling interests seize on the controversy, says Richard Mott, vice-president for international policy at the environmental organization WWF in Washington DC, it will beimportant to point out that debate is part of good science. "This shows that on the conservation side the standards for debate and peer review are very rigorous, which is not the case in the pro-whaling countries," he claims.
US bombshell hits revamp of Russian weapons centres

\section{Geoff Brumfiel, Washington}

A US-funded scheme to turn the secret cities that developed Russia's nuclear arsenal into commercial centres could come to end this September.

Officials at the US Department of Energy (DOE), which runs the scheme, say that the Nuclear Cities Initiative must close unless Russia accepts liability for American workers and companies on the project. But arm-controls experts charge that this is a convenient excuse used to kill a programme that is unpopular with the Bush administration.

The scheme, which was born in 1998 and currently consumes around US\$15 million in funds annually, has been hampered by problems. Some Russian weapons centres have been reluctant to grant access to their sites, and a 1999 report by the US General Accounting Office said that too little money was reaching Soviet scientists.

Despite this, the initiative has support within the arms-control community, as it is the only US programme aimed at converting weapons facilities to civilian uses. The scheme has had some early successes, such as the shutdown of a nuclear warhead production plant in the formerly closed Russian city of Sarov.

But on 22 July, US energy secretary Spencer Abraham told Alexander Rumyantsev, Russia's atomic-energy minister, that he will not renew the agreement when it expires in September. In a statement, Abraham said the scheme could not continue unless Russia agreed to accept legal liability for US companies and scientists working in the cities, including protection from prosecution in the event of an accident. The Russian parliament is currently in recess and is unlikely to to address the issue before the September deadline has passed.

Supporters of the programme question the administration's motives. "The liability issue is a red herring," says Rose Gottemoeller of the Carnegie Endowment for International Peace in Washington, who led the DOE's nonproliferation bureau under the Clinton administration. Gottemoeller points out that the Bush administration tried to cut the programme in 2001, but that funding was restored after the terrorist attacks of 11 September 2001.

US energy undersecretary Robert Card says that the DOE will back currently funded projects to completion. www.nn.doe.gov/nci 